Agric. Biol. Chem, 42 (1), 49 54, 1978

\title{
API-2b, a New Alkaline Protease Inhibitor Produced by Streptomyces griseoincarnatus Strain No. KTo-250
}

\author{
Masaru UyEDA, Keitarou SUZUKI, Hiroko UWATOKo \\ and Motoo Shibata \\ Laboratory of Medicinal Microbiology, Faculty of Pharmaceutical Sciences, \\ Kumamoto University, Kumamoto City 862, Japan
}

Received July 28, 1977

\begin{abstract}
To obtain new alkaline protease inhibitors, further screening test was carried out. A strain (No. KTo-250), identified as Streptomyces griseoincarnatus was found to produce three kinds of inhibitors designated as API-2a, b and $c$ in the order of mobilities from cathode terminal of the polyacrylamide gel.

First of all, API-2b was purified and this inhibitor differed from AP-I and S-SI in the mobility on polyacrylamide gel disc electrophoresis and $\mathrm{pH}$ stability and molecular weight.
\end{abstract}

To obtain actinomycetes capable of producing new enzyme affectors, we have been screening actinomycetes which produced enzyme inhibitor or activator in their culture broth. In the previous paper, ${ }^{1}$ ) we reported that alkaline protease inhibitor, AP-I, was produced in the culture filtrate of Streptomyces pseudogriseolus strain No. KTo-332, and purification, crystallization and some properties of this inhibitor were also described. ${ }^{2}{ }^{2}$ Though AP-I differed from S-SI with respects to the behavior on EI complex formation $^{37}$ and no inhibition of $\alpha$-chymotrypsin and trypsin in the case of $p$-nitrophenyl acetate as substrate, ${ }^{2)}$ this inhibitor seems to have similar characteristics as S-SI. ${ }^{4 \sim 6)}$ To obtain new inhibitors, further screening tests were carried out and a new alkaline protease inhibitor was found to be produced in the culture filtrate of Streptomyces griseoincarnatus strain No. KTo-250. Hereafter, this inhibitor is referred to as API-2. In the present paper, the classification of the strain, the purification procedure of API-2b and some differences among this inhibitor and AP-I and S-SI are mainly described

\section{MATERIALS AND METHODS}

Enzymes. Alkaline protease was purified in our laboratory from Taka-diastase (purchased from Sankyo
Co., Ltd.). For the screening, or routine assay, Takadiastase itself was used as the source of alkaline protease. Subtilisin BPN' (Nagase Co., Ltd.), trypsin (Sigma Chemical Co.), a-chymotrypsin (Sigma Chemical Co.) and pronase AS (Kaken Kagaku Co., Ltd.) were purchased. Cephalosporium sp. alkaline protease $^{7)}$ was kindly provided by Fujisawa Pharmaceutical Co. Subtilisin Carlsberg was kindly provided by Professor D. Tsuru of Nagasaki University.

Assay for the inhibitory activity. The mixture of $1 \mathrm{ml}$ of the enzyme solution and $1 \mathrm{ml}$ of borax- $\mathrm{NaOH}$ buffer $(0.2 \mathrm{M}, \mathrm{pH} 9.5)$ with or without inhibitor was incubated at $37^{\circ} \mathrm{C}$ for $5 \mathrm{~min}$. Then $1 \mathrm{ml}$ of $2 \%$ casein solution was added. After incubation for $15 \mathrm{~min}$ at $37^{\circ} \mathrm{C}, 2 \mathrm{ml}$ of $12 \%$ perchloric acid solution was added to stop the reaction and the mixture was allowed to stand for $30 \mathrm{~min}$ at room temperature. The filtrate was assayed for enzyme activity by measuring the extinction at $660 \mathrm{~nm}$ according to the method of Lowry's colorimetry. ${ }^{8)}$ One inhibitor unit was defined as the dose at which alkaline protease from Taka-diastase is inhibited by $50 \%$ of its caseinolytic activity in this assay system.

Disc electrophoresis. Polyacrylamide gel disc electrophoresis was carried out at pH's 8.0 (Veronal buffer), and 2.3 (glycine-acetate buffer). A sample (15 $\mu \mathrm{g}$ protein) was applied on the top of the stacking gel $(7.5 \%$ acrylamide) and run at the constant current of $3 \mathrm{~mA}$ per gel column for $60 \mathrm{~min}$. After electrophoresis the gel was stained with Amido black 10B and destained with $7 \%$ acetic acid solution.

Screening for new alkaline protease inhibitor. About 60 strains of actinomycetes, which had been screened by primary screening method and showed possibility of 
the production of enzyme affectors, were inoculated to $200 \mathrm{ml}$-Erlenmeyer flask with $40 \mathrm{ml}$ of the medium containing $2 \%$ glucose, $3 \%$ soluble starch, $1 \%$ soybean flour, $1 \%$ corn steep liquor, $0.5 \%$ Polypepton, $0.3 \%$ $\mathrm{NaCl}$ and $0.5 \% \mathrm{CaCO}_{3}(\mathrm{pH} 7.0)$. These cultures were cultivated at $28^{\circ} \mathrm{C}$ for 1 to 3 days on rotary shaker (180 rpm, $5 \mathrm{~cm}$ radius). Everyday, a portion of the culture was filtered and the filtrate was used for both the measurement of inhibitory activity and polyacrylamide gel disc electrophoresis at $\mathrm{pH}$ 8.0.

\section{Taxonomical studies of Streptomyces sp. strain No. KTo-} 250.

1) Streptomyces sp. strain No. KTo-250. The strain was isolated from a soil sample collected in Kumamoto City, Japan. This strain was used throughout this work.

2) Morphological observation. The culture of strain No. KTo-250 incubated on a glucose-asparagine agar at $28^{\circ} \mathrm{C}$ for 7 days was observed by a light microscope and an electron microscope (JEM-50B, Japan Electron Optics Laboratory, Co., Ltd.).

3) Cultural characteristics. Each of the media used in this study was prepared according to the description of S. A. Waksman. ${ }^{9)}$ Spores of the strain collected from the 7-days culture on a yeast extract-malt extract agar were suspended in sterilized water and a loopful of the suspension was added to each of the media. The strain was cultivated at $28^{\circ} \mathrm{C}$ for 14 days and observations were carried out on every 7 days after inoculation. The color names were based on Rayner's description. ${ }^{10)}$

4) Utilization of carbon sources. Examination of carbon utilization was made according to Pridham's method. ${ }^{\text {in }}$

\section{RESULTS AND DISCUSSION}

\section{Result of screening test}

After screening test, most of alkaline protease inhibitors produced by the strains of actinomycetes migrated with similar mobility as AP-I in polyacrylamide gel disc electrophoresis at pH 80 , but only the inhibitor produced by strain No. KTo-250 showed the different result from other inhibitors, therefore, further studies were made using this strain.

\section{Taxonomical studies of strain No. KTo-250}

Morphological, cultural and phisiological characteristics of the strain were examined and summarized in Table I. Based on the taxonomical characteristics such as grey series
Table I. Taxonomical Characteristics of Streptomyces sp. STRAIN No. KTo-250

Spore chain morphology: Aerial mycelium produce numerous open spirals. Spores shaped oval. Spore surface; spiny.

Color of colony: Aerial mass color in the gray series; white to pale mouse gray (Rayner's color chart, sheet 7, VI-117) or pale purplish gray (sheet 7, VI-127) on Czapek's agar, glucose-Czapek's agar, glycerol nutrient agar, yeast extract agar and starch agar etc.

Reverse side of colony: No distinctive pigments are formed (colorless or yellowish on various media).

Color in medium: Melanoid pigments are not produced in peptone-yeast extract-iron agar, tyrosine agar or nutrient agar. No pigment is found in medium in yeast extract-malt extract agar, oatmeal agar, salts-starch agar or glucose-asparagine agar. Pale luteous (sheet $1, \mathrm{I}-11$ ) to dark brick (sheet 4, III-60) pigment in Czapek's and glucose or glycerin Czapek's agar. Sienna (sheet $1, \mathbf{I}-8$ ) pigment in glycerin or glucose nutrient agar.

Physiological characteristics:

Gelatin liquefaction: Positive, strong.

Starch hydrolysis: Positive, strong; enzymatic zone/growth zone $30 \sim 34 \mathrm{~mm} / 13 \mathrm{~mm}$ in 1 week.

Chromogenicity: Negative.

Peptonization of milk: Positive.

Coagulation of milk: Positive.

Cellulose decomposition: Negative.

Nitrate reduction: Negative.

Carbon utilization: Positive on D-glucose, Larabinose, sucrose, D-xylose, meso-inositol, D-mannitol, D-fructose and rhamnose. Negative on raffinose.

Mesophilic (opt. temperature: $28^{\circ} \mathrm{C}$ ) and aerobic. Antimicrobial activity: Exhibits antibacterial (Gram-positive) and antifungal activity.

of spore mass color, spiral formation, no melanoid pigments, spiny spore surface and carbon utilization according to "Bergey's Manual of Determinative Bacteriology" ( 8 th edition, 1974), ${ }^{121}$ the strain has good resemblance to Streptomyces griseoincarnatus. The strain, therefore, was identified as a strain belonging to Streptomyces griseoincarnatus ${ }^{13}$ ) and named as Streptomyces griseoincarnatus strain No. KTo-250.

Time course of strain No. KTo-250 culture

For the best production of API-2, the cul- 
Table 1I. Cultural Conditions for the Production of API-2

Strain used: Streptomyces griseoincarnatus strain No. KTo-250

Seed culture medium (S medium):

glucose 2.0, starch 3.0, C.S.L. 1.0, S.B.F. 1.0, peptone $0.5, \mathrm{NaCl} 0.3, \mathrm{CaCO}_{3} 0.5(\%)$

Main culture medium:

glucose 2.0 , peptone 2.0 , yeast extract $0.1, \mathrm{NaCl}$ $0.1, \mathrm{~K}_{2} \mathrm{HPO}_{4} 0.1, \mathrm{MgSO}_{4} \cdot 7 \mathrm{H}_{2} \mathrm{O} 0.05(\%)$

Initial $\mathrm{pH}$ : 7.0

Culture volume:

$40 \mathrm{ml}$-medium/200 ml-Erlenmeyer flask

Inoculum size: $\quad 2 \mathrm{ml} / 40 \mathrm{ml}$-medium $(5 \%$ seed $)$

Cultural temperature: $28^{\circ} \mathrm{C}$

Agitation:

$180 \mathrm{rpm}$

tural conditions including the composition of medium were examined and the optimal conditions are summarized in Table II. Based on the cultural conditions, cultivation of this strain was carried out. Time course changes in inhibitory activity, protein, residual glucose in culture filtrate, growth of mycelium, $\mathrm{pH}$ of the broth and polyacrylamide gel disc electrophoresis of culture filtrate are shown in Fig. 1. With the consumption of glucose, mycelium

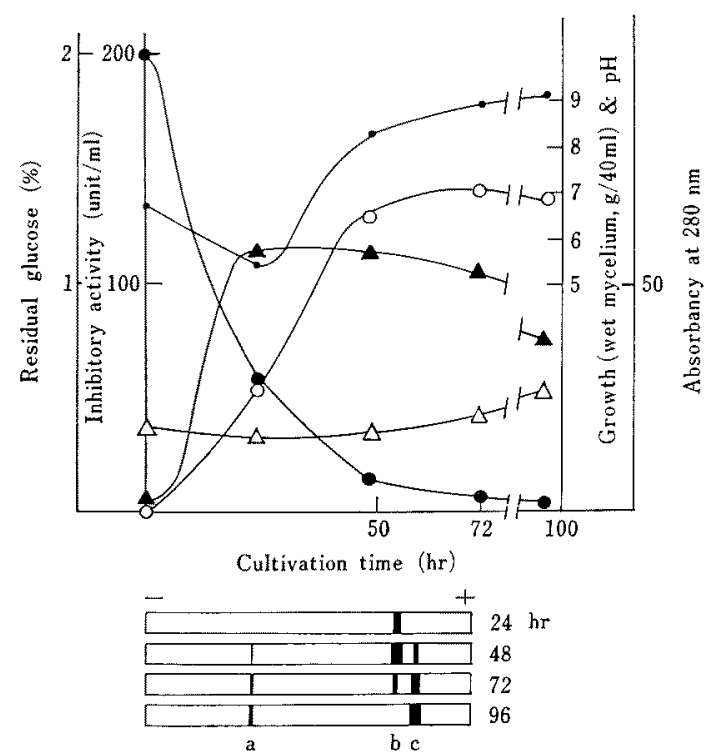

FIG. 1. Time Course of Streptomyces griseoincarnatus Strain No. KTo-250 Culture.

$O$, inhibitory activity; $\bullet$, residual glucose; $\triangle$, absorbancy at $280 \mathrm{~nm} ; \wedge$, growth; $\cdot, \mathrm{pH}$. grew and reached stationary phase around $24 \mathrm{hr}$ of cultivation. Inhibitory activity reached maximum after $72 \mathrm{hr}$ and it was maintained almost stably even after more $24 \mathrm{hr}$. At the time indicated, polyacrylamide gel disc electrophoresis was carried out at $\mathrm{pH} \quad 8.0$ using each culture filtrate. With cultivation time, 3 bands appeared in the gel. It was recognized by separate experiment that either of these 3 bands has inhibitory activity. As a result, this strain was found to produce 3 kinds of alkaline protease inhibitors. These bands were named as API- $2 a, b$ and $c$ in the order of their mobilities from cathode terminal of the gel. Among them, there is close relationship between $\mathrm{b}$ and $\mathrm{c}$, since $\mathrm{b}$ is converted into $c$, as will be described in detail in the next paper. On the other hand, API-2a was thought to be independent of $b$ and $c$.

\section{Production and purification of $A P I-2 b$}

To get API- $2 b$, first of all, the cultivation was stopped in $24 \mathrm{hr}$, since there is no API-2a and $\mathrm{c}$ until then. After cultivation, the culture was filtered through filter paper. Overall purification procedure of API-2b is summarized in Fig. 2. At first, to the clear filtrate was added solid ammonium sulfate to give $40 \%$ saturation. After standing overnight at $4{ }^{\circ} \mathrm{C}$, the precipitate was collected by centrifugation, dissolved in a minimal volume of $0.02 \mathrm{M}$ boric acid-borax buffer ( $\mathrm{pH} 7.5$ ) and then dialyzed against the same buffer for 2 days to be free from ammonium sulfate. This solution was applied on a DEAE-cellulose column which had been equilibrated with the same buffer.

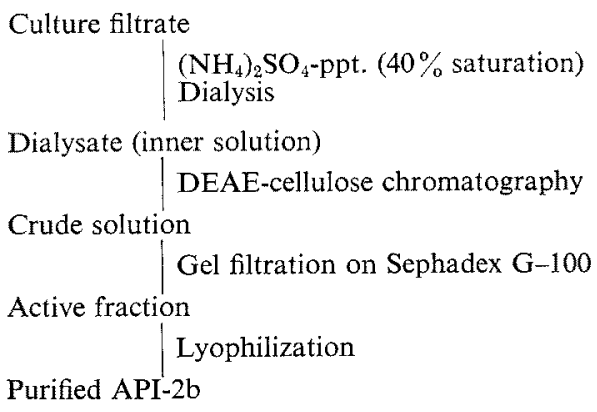

FIG. 2. Purification of API-2b from Culture Filtrate of Strain No. KTo-250. 
API-2b was eluted with the same buffer containing linear concentration of $\mathrm{NaCl}$ from 0 to $0.5 \mathrm{M}$. The elution pattern was shown in Fig. 3. The active fractions (tube Nos. $22 \sim 30$ ) were combined and solid ammonium sulfate was added to $40 \%$ saturation.

The resulting precipitate was dissolved in a minimal volume of $0.02 \mathrm{M}$ boric acid-borax buffer ( $\mathrm{pH} 7.5$ ) containing $0.1 \mathrm{M} \mathrm{KCl}$, and then dialyzed against the same buffer for 2 days at

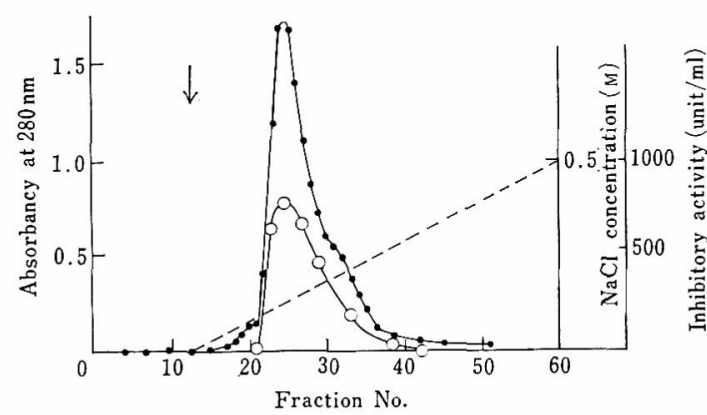

FIG. 3. Column Chromatography of API-2b on DEAE-cellulose.

Column size, $2 \times 7 \mathrm{~cm}$; flow rate, $8 \mathrm{ml} / \mathrm{hr}$; fraction size, $4 \mathrm{ml}$; buffer system, $0.01 \mathrm{M}$ boric acid-borax buffer $(\mathrm{pH} 7.5)$ and the same buffer containing linear concentrations of $\mathrm{NaCl}$ from 0 to $0.5 \mathrm{M}$ (started at the point marked by arrow). $\mathrm{O}-\mathrm{O}$, inhibitory activity; -- absorbancy at $280 \mathrm{~nm}$; ------, $\mathrm{NaCl}$ concentration.

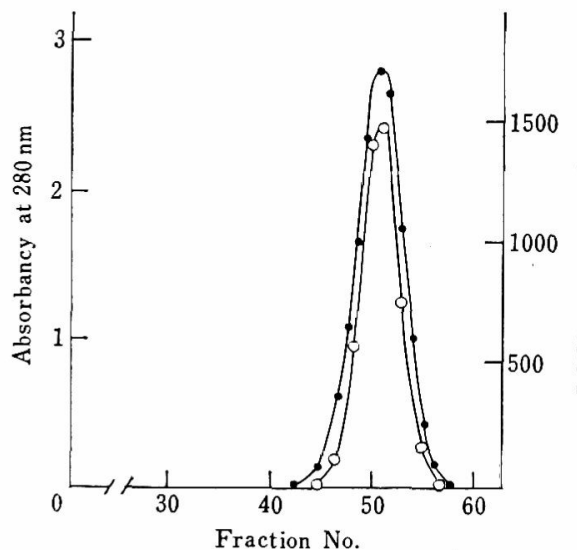

FIG. 4. Gel Filtration of API-2b on Sephadex G100.

Buffer, boric acid-borax $(0.02 \mathrm{M}, \mathrm{pH} 7.5)$ containing $0.1 \mathrm{M} \mathrm{KCl}$; column size, $1.8 \times 90 \mathrm{~cm}$; flow rate, $18 \mathrm{ml} /$ $\mathrm{hr}$; fraction size, $3 \mathrm{ml}$. $\mathrm{O}-\mathrm{O}$, inhibitory activity; -—, absorbancy at $280 \mathrm{~nm}$.

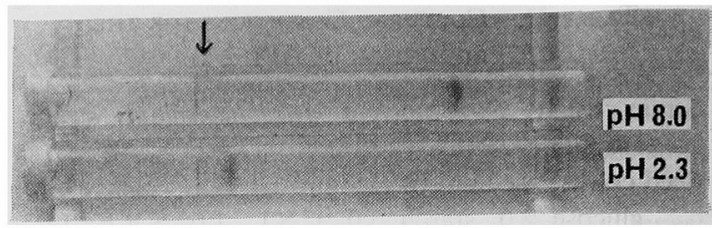

FIG. 5. Polyacrylamide Gel Disc Electrophoresis of API-2b.

Arrow indicates the position of sample applied (15 $\mu \mathrm{g}$ of purified API-2b).

$4^{\circ} \mathrm{C}$. Then the crude solution thus obtained was applied on a Sephadex G-100 column previously equilibrated with the above dialyzing buffer, and eluted with the same buffer. The elution pattern is shown in Fig. 4. The active fractions (tube Nos. $47 \sim 54$ ) were combined and solid ammonium sulfate was added to $40 \%$ saturation. The resulting precipitate was dissolved in a minimal volume of distilled water, and dialyzed against water to remove any salt and then lyophilized.

Homogeneity of lyophilized API-2b was examined by polyacrylamide gel disc electrophoresis. As shown in Fig. 5, API-2b migrated as a single, clear band, so it was regarded to be homogeneous. Recovery of API-2b from the culture filtrate is shown in Table III.

Table III. Summary of Purification of API-2b from the CUIture Filtrate of Strain No. KTo-250

\begin{tabular}{|c|c|c|c|}
\hline & $\begin{array}{l}\text { Total } \\
\text { activity } \\
\text { (unit) }\end{array}$ & $\begin{array}{c}\text { Specific } \\
\text { activity } \\
\text { (unit/ } \\
\mathrm{OD}_{280} \text { ) }\end{array}$ & $\begin{array}{c}\text { Recovery } \\
(\%)\end{array}$ \\
\hline Culture filtrate & 182000 & 3.4 & 100 \\
\hline Dialysate & 134000 & 237.8 & 73.4 \\
\hline Crude solution $^{a}$ ) & 83000 & 553.0 & 45.3 \\
\hline Active fraction $\left.{ }^{b}\right)$ & 73000 & 650.0 & 40.2 \\
\hline Purified API-2b & 71000 & 678.1 & 38.8 \\
\hline $\begin{array}{l}\text { a) After columt } \\
\text { lulose. }\end{array}$ & UII & phy & DEAE-cel- \\
\hline
\end{tabular}

Comparison of API-2b with AP-I by polyacrylamide gel disc electrophoresis

For the comparison of API-2b with AP$\mathrm{I},{ }^{1 \sim 3)}$ both inhibitors were applied on polyacrylamide gel disc electrophoresis at $\mathrm{pH}$ 8.0. As 


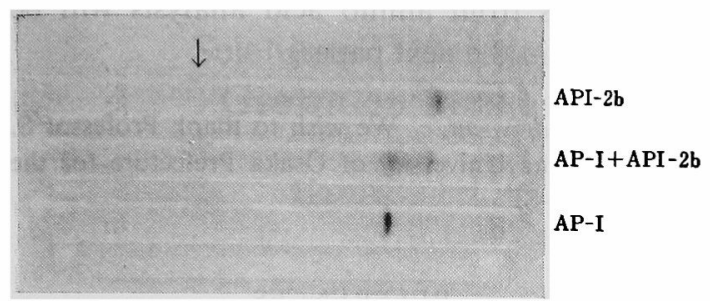

FIG. 6. Comparison of API-2b with AP-I by Disc Electrophoresis.

Arrow indicates the position of sample applied. Polyacrylamide gel disc electrophoresis was carried out at $\mathrm{pH} 8.0$ at $3 \mathrm{~mA}$ per gel column.

shown in Fig. 6, API-2b showed different mobility $(R f 0.79)$ from AP-I $(R f 0.65)$, and migrated toward anode more than AP-I. By the way, S-SI showed the almost same mobility $(R f 0.66)$ as AP-I.

\section{$p H$ and temperature stability of $A P I-2 b$}

Stability of API-2b was tested in buffer solutions of various $\mathrm{pH}$ 's at $37^{\circ} \mathrm{C}$ for $20 \mathrm{hr}$ and $100^{\circ} \mathrm{C}$ for $10 \mathrm{~min}$. Residual activity was measured at $\mathrm{pH}$ 9.5. The following buffer systems were used in each $0.05 \mathrm{M}$ : $\mathrm{HCl}-\mathrm{KCl}$

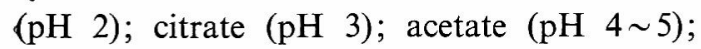
phosphate ( $\mathrm{pH} 6 \sim 8)$; boric acid-borax $(\mathrm{pH} 9)$; borax- $\mathrm{NaOH}$ (pH $10 \sim 11)$. As shown in Fig. 7 , API-2b was stable in $\mathrm{pH}$ range from 5 to 11 at $37^{\circ} \mathrm{C}$ for $20 \mathrm{hr}$. After treatment at $100^{\circ} \mathrm{C}$ for $10 \mathrm{~min}$, API-2b retained its inhibitory activity in $\mathrm{pH}$ range from 6 to 8 .

So, API-2b was more stable than $\mathrm{AP}-\mathrm{I}^{2}$ in acidic range of $\mathrm{pH}$ at $37^{\circ} \mathrm{C}$ for $20 \mathrm{hr}$, while, by the treatment at $100^{\circ} \mathrm{C}$ for $10 \mathrm{~min}, \mathrm{API}-2 \mathrm{~b}$

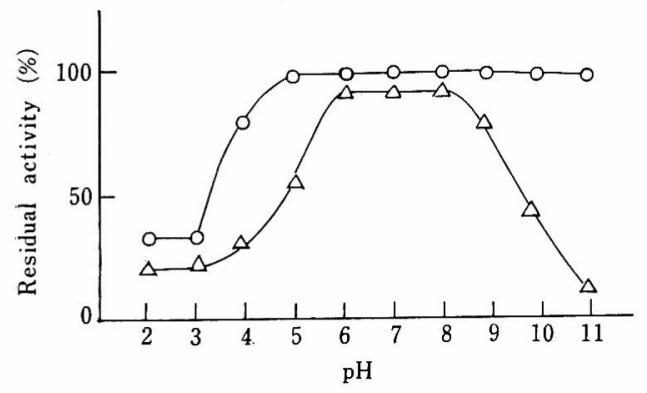

FIG. 7. $\mathrm{pH}$ and Thermal Stability of API-2b. $\mathrm{O}-\mathrm{O}, 37^{\circ} \mathrm{C}, 20 \mathrm{hr} ; \triangle \longrightarrow \triangle, 100^{\circ} \mathrm{C}, 10 \mathrm{~min}$. Buffer system used was described in the text. Residual inhibitory activity was measured at $\mathrm{pH} 9.5$. was not more stable than AP-I. In comparison of API-2b with S-SI, API-2b was different from S-SI in $\mathrm{pH}$ stability. Murao et al. reported $^{5)}$ that S-SI was very stable in wide $\mathrm{pH}$ range ( $\mathrm{pH}$ 's $3 \sim 11$ ) at $37^{\circ} \mathrm{C}$ for $25 \mathrm{hr}$ and $\mathrm{S}-\mathrm{SI}$ retained its perfect activity in $\mathrm{pH}$ range from 4 to 6 at $100^{\circ} \mathrm{C}$ for $10 \mathrm{~min}$.

\section{Molecular weight of $A P I-2 b$}

The molecular weight of API-2b was estimated according to the method of Andrews ${ }^{14)}$ with a Sephadex G-100 column. Gel filtration was carried out at $4^{\circ} \mathrm{C}$ in $0.02 \mathrm{M}$ boric acid-borax buffer ( $\mathrm{pH} 7.5$ ) containing $0.1 \mathrm{M}$ $\mathrm{KCl}$. In Fig. 8, the ratio of elution volume to void volume is plotted against the logarithm of molecular weight for each reference protein and API-2b. From the result, an approximate molecular weight of 36,000 was obtained for API-2b.

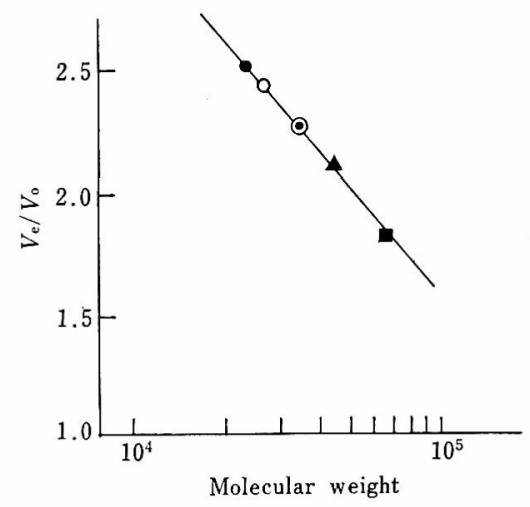

FIG. 8. Plots of $V_{\mathrm{e}} / V_{\mathrm{o}}$, against Log. of Molecular Weight for API-2b, AP-I and Authentic Samples on Sephadex G-100 Column.

-, trypsin (MW: 24,000); $\Delta$, ovalbumin (MW: 46,000 ); $\boldsymbol{a}$, bovine serum albumin (MW: 67,000); O, AP-I (MW: 27,500); $\odot$, API-2b.

Inhibitory effect of API-2b on various proteases Inhibitory effect of API-2b on various proteases was examined. The conditions for the caseinolytic activity of each protease were adjusted so as to give the value of 0.7 of the extinction at $660 \mathrm{~nm}$ in the Lowry's method of casein hydrolysate. The results are listed in Table IV. The inhibition was expressed as 
TABle IV. EFFEct OF API-2b ON VARious Proteases

\begin{tabular}{|c|c|c|}
\hline Protease & $\mathrm{pH}$ & Inhibition \\
\hline $\begin{array}{l}\text { Alkaline protease from } \\
\text { Taka-diastase }\end{array}$ & 9.5 & + \\
\hline Subtilisin BPN' & 9.5 & + \\
\hline Subtilisin Carlsberg & 9.5 & + \\
\hline $\begin{array}{l}\text { Alkaline protease } \\
\text { (Nagase) }\end{array}$ & 9.5 & $t$ \\
\hline Pronase AS & 9.5 & \pm \\
\hline $\begin{array}{l}\text { Alkaline protease from } \\
\text { Cephalosporilum sp. }\end{array}$ & 9.5 & + \\
\hline $\begin{array}{l}\text { Neutral protease from } \\
\text { Bacillus subtilis }\end{array}$ & 7.0 & - \\
\hline Trypsin & 7.0 & - \\
\hline$\alpha$-Chymotrypsin & 7.0 & - \\
\hline Pepsin & 2.0 & - \\
\hline
\end{tabular}

plus when more than $90 \%$ inhibition took place, and minus when the inhibition was less than $10 \%$ in the presence of $100 \mu \mathrm{g}$ each of API- $2 b$.

API-2b showed strong inhibition for microbial alkaline proteases but did not inhibit other serine proteases from animal tissues. As for inhibitory spectrum, API-2b seems to have similar characteristics as AP-I and S-SI. However, as so far described, different results were obtained from $\mathrm{AP}-\mathrm{I}$ and $\mathrm{S}-\mathrm{SI}$ in $\mathrm{pH}$ and temperature stability, mobility on polyacrylamide gel disc electrophoresis and molecular weight. Recently, we found further difference between API-2b and AP-I, that is API-2b (also API-2c) contained isoleucine residue in the molecule. Other differences including the results from amino acid analysis will be described in the next paper.

Acknowledgement. We wish to thank Professor S. Murao in the University of Osaka Prefecture for the supply of S-SI.

\section{REFERENCES}

1) M. Uyeda, S. Yoshida, K. Suzuki and M. Shibata, Agric. Biol. Chem., 40, 1237 (1976).

2) M. Uyeda, K. Suzuki, Y. Umemoto, I. Matsuzaki and M. Shibata, ibid., 41, 703 (1977).

3) M. Uyeda, K. Suzuki and M. Shibata, ibid., 40, 1479 (1976).

4) S. Murao, S. Sato and N. Muto, ibid., 36, 1737 (1972).

5) S. Sato and S. Murao, ibid, 37, 1067 (1973).

6) K. Inouye, B. Tonomura and K. Hiromi, ibid, 39, 1159 (1975).

7) J. Yagi, T. Yano, Y. Kubochi, S. Hattori, M. Ohashi, H. Sakai, K. Jomon and M. Ajisaka, $J$. Ferment. Fechnol., 50, 592 (1972).

8) O. H. Lowry, N. J. Rosebrough, A. L. Farr and R. J. Randall, J. Biol. Chem., 193, 265 (1951).

9) S. A. Waksman, "The Actinomycetes," Vol. II, The Williams and Wilkins Co., Baltimore, M. D., 1961, p. 328 334.

10) R. W. Rayner, "A Mycological Color Chart," Commonwealth Mycological Inst., Kew, Surrey and British Mycological Soc., 1970.

11) T. Pridham and D. Gottlieb, J. Bacteriol., 56, 107 (1948).

12) "Bergey's Manual of Determinative Bacteriology" 8 th Edition, ed. by R. E. Buchanan and N.E. Gibbons, The Williams and Wilkins Co., Baltimore, M. D., 1974, p. $747 \sim 845$.

13) T. G. Pridham, C. W. Hesseltine and R. G. Benedict, Appl. Microbiol., 6, 52 (1958).

14) P. Andrews, Biochem. J., 96, 595 (1965). 